\title{
TEORIA RÓL JAKO METODA BADANIA MIAST PODZIELONYCH GRANICA
}

\section{Role Theory as a Method of Studying Divided Cities}

The problem of divided cities is not new, yet it must be admitted that the political science approach is a definite minority among numerous, primarily geographical and historical approaches. This article contains a review of the current achievements and the state of research in this area, and also indicates the most popular methods, theories and topics that enjoy the greatest research interest, while highlighting their strengths and weaknesses. It also offers a slightly different approach to the problems of divided cities, including an analysis of their international potential considered from the perspective of role theory. This approach treats divided cities as entities building their own power (based primarily on soft power), assuming, however, that the capabilities of each of the 'twin' parts of a city are different and not necessarily symmetrical for various reasons.

Keywords: role theory, divided cities, leadership, power, identity, position.

\section{WPROWADZENIE}

Tekst składa się $z$ trzech części. Pierwsza stanowi syntetyczna prezentację dotychczasowego podejścia w ramach badań nad kwestia miast podzielonych $z$ uwzględnieniem przyjętego aparatu pojęciowego i metodologii. Druga to krytyczne podejście ukazujące zarówno silne, jak i słabe strony prowadzonych badań w obszarze miast podzielonych. Trzecia i ostatnia część jest próbą nieco odmiennego spojrzenia 
na interesujące nas zagadnienie, a mianowicie ukazanie podzielonego granica miasta $z$ perspektywy jego potencjału, „potęgi”, którą posiada i którą ewentualnie stara się wykorzystać (lub też nie, ze względu na szereg różnych czynników) do dalszego swojego rozwoju.

Przyjęta metoda badawcza będzie miała charakter analityczny i na ostatnim swoim etapie oprze się w swym teoretycznym założeniu zarówno na teorii ról międzynarodowych, jak i definicji potęgi właśnie. Ujęcie takie, aczkolwiek nietradycyjne, nie jest obce badaczom interesującego nas zagadnienia. Wystarczy wymienić tu chociażby pracę Radosława Zenderowskiego i Mateusza Kryckiego ${ }^{1}$, którzy odwołuja się w swych analizach do public dyplomacy i soft power, czy Jarosława Jańczaka piszącego o potencjale miast podzielonych granica ${ }^{2}$.

Głównymi pytaniami badawczymi, które stana się centrum rozważań sa następujące kwestie: 1. Czy miasta podzielone granica moga i de facto odgrywaja określone role międzynarodowe? 2. Jeśli tak, to jaka rolę przyjmuja i wobec kogo ją odgrywają: wobec regionu czy wobec swojej „bliźniaczej” części? 3. Czy role te sa przez inne podmioty i aktorów systemu politycznego akceptowane czy też kwestionowane? Czy miasta podzielone granica mogą budować swoją własna (odrębna względem siebie) potęgę (power) czy też wola „podczepiać się” jako mali aktorzy międzynarodowi do regionu, z którym się utożsamiaja, czy też może ostatecznie dąża, mimo granicy, do maksymalizacji swojej „zjednoczonej” siły? 4. Jakie czynniki determinują i decyduja o ich zachowaniu i przyjętej strategii? 5. Jakie są konsekwencje przyjętych przez nie działań i jak się one przekładaja na ich pozycję w kraju, regionie i względem siebie?

\section{DOTYCHCZASOWY STAN BADAŃ}

Miasta podzielone granica bywają określane przez badaczy zarówno jako pewien fenomen ${ }^{3}$, jak też i anomalia. Fenomen choćby $z$ tego względu, iż w zasadzie są domeną europejska, można się ich tu doli-

\footnotetext{
1 Zob. R. Zenderowski, M. Krycki, Public diplomacy $w$ miastach podzielonych granica państwowa. Przykład Cieszyna i Czeskiego Cieszyna (Český Tëšin), „Pogranicze. Polish Borderlands Studies" 2014, t. 2, nr 2, s. 206-227.

2 Zob. J. Jańczak, Miasta (trans)graniczne jako uczestnicy procesu integracji europejskiej, „Teka of Political Science and International Relations” 2013, nr (8), s. 53-63.

3 Zob. R. Zenderowski, M.M. Brzezińska, Miasta podzielone granica państwowa $w$ nowych państwach członkowskich UE: od separacji do integracji, „Pogranicze. Polish Borderlands Studies" 2014, t. 2, nr 2, s. 168.
} 
czyć $19^{4}$, przy czym aż 5 (lub licząc jako miejscowości 7$)^{5}$ na granicy $z$ Polską. Nadto tworza one swoiste mikrośrodowiska i mikrosystemy mogace chociażby stanowić niezwykle bogate źródło badań procesów integracyjnych (miasta jako laboratoria integracji europejskiej), jak i dezintegracyjnych. Stanowia zaś swego rodzaju kuriozum dlatego, że często nie powstały w sposób naturalny, ale jako wynik schyłku feudalizmu, dziedzictwo okresu napoleońskiego ${ }^{6}$ czy jako „skrajnie nieludzki”, „okrutny eksperyment” i efekt podziałów politycznych majaccych miejsce po I czy II wojnie światowej ${ }^{7}$ (zwłaszcza te na granicach wewnętrznych Unii Europejskiej). Miasta stanowiące kiedyś swoista jedność podzielono, jak zauważa Zenderowski, „z takim samym wdziękiem, $z$ jakim w sklepie mięsnym rąbie się wołowe $z$ kością"

Miasta podzielone granica sa także wdzięcznym ${ }^{9}$ i niełatwym przedmiotem badań naukowych. Wdzięcznym ze względu na interdyscyplinarność i złożoność zachodzących w nim procesów i zjawisk. Jako obszar stanowiący część pogranicza, ścierają się bowiem na nim zarówno koncepcje regionalizacji, jak i peryferyzacji. Złożonym zaś ze względu sama granice (rozumiana zarówno jako boundary, jak i frontier ${ }^{10}$ ), która znacznie komplikuje, a czasem i uniemożliwia prowadzenie równoległych analiz, decydująco wpływając na wyniki badań końcowych. Każda jednak trudność jest dla badacza intrygująca i stanowi wyzwanie, co ma miejsce także w przypadku miast podzielonych granica.

W zasadzie wszyscy badacze zajmujący się kwestią miast podzielonych pozostaja zgodni co do tego, iż podmiot ich dociekań wykazuje się dużym stopniem różnorodności i wielopłaszczyznowości, ciesząc się zainteresowaniem rozmaitych dziedzin i dyscyplin naukowych ${ }^{11}$. Wymienić tu można chociażby specjalistów z zakresu socjologii,

4 Stan na dzień 31.03.2014 r. Zob. K. Kulczyńska, Miasta podzielone jako przedmiot zainteresowań geografii oraz innych nauk, „Rozwój Regionalny i Polityka Regionalna” 2013, nr 24, s. 51.

5 K. Kulczyńska podaje, iż na granicy $z$ Polska jest 5 miast podzielonych granica, natomiast R. Zenderowski i M. Brzezińska doliczaja jeszcze dwie inne miejscowości (nie miasta), co w efekcie daje liczbe 7.

6 Zob. R. Zenderowski, M. Brzezińska, Miasta podzielone..., s. 168.

Zob. R. Zenderowski, M. Krycki, Public diplomacy..., s. 206.

8 R. Zenderowski, Cieszyn cieszy - Cieszyn smuci. Miasto podzielone granica państwowa jako środkowoeuropejskie miejsce pamięci, w: Wspólne czy osobne? Miejsca pamięci narodów Europy Wschodniej, red. W. Śleszyński, Białystok-Kraków 2011, s. 206-207.

9 Zob. R. Zenderowski, M. Brzezińska, Miasta podzielone..., s. 167.

10 Więcej na ten temat pisał J. Jańczak, Integracja i dezintegracja w Europie Środkowej. Graniczne miasta bliźniacze jako laboratoria wspótpracy transgranicznej, „Rocznik Integracji Europejskiej” 2013, nr 7, s. 266.

${ }_{11}$ Zob. K. Kulczyńska, Miasta podzielone jako przedmiot... czy R. Zenderowski, M.M. Brzezińska, Miasta podzielone... 
geografii, politologii, historii, ekonomii, kulturoznawstwa, stosunków międzynarodowych, prawa i wielu innych. Jak podkreśla Jarosław Jańczak, zauważalne sa też, w kontekście wybranych miast podzielonych granica, okresowe nasilanie się wybranych dyscyplin. Za przykład podaje granice polsko-niemiecka, gdzie:

[...] pogranicze polsko-niemieckie w latach powojennych było przede wszystkim przedmiotem analiz prawnych i prawnomiędzynarodowych, potwierdzajacych, uzasadniających lub kontestujących przebieg granicy. Dalej, w podobnym celu pograniczem zajmowali się historycy i archeolodzy. Przesiedlenia ludności przyciagnęły uwagę socjologów i antropologów. Otwarcie granicy i rozwój współpracy sprawiły, iż obszar ten stał się tematycznie atrakcyjny dla politologów, ekonomistów, specjalistów od migracji, etc. ${ }^{12}$

Ponieważ też miasta podzielone granicą państwową są głównie domeną europejska (pisali o tym chociażby wspomniani Katarzyna Kulczyńska czy Radosław Zenderowski), przyją się ich podział na tzw. miasta rozłupane na pół oraz powstałe obok siebie (stykowe). Pierwsze dominuja głównie w Europie Środkowo-Wschodniej i Południowo-Wschodniej ${ }^{13}$, drugie zaś w Europie Zachodniej i Europie Północnej ${ }^{14}$, co znaczaco determinuje charakter prowadzonych badań.

Podział Europy, wynikający z powojennych ustaleń politycznych, zdeterminował nie tylko przestrzeń, ale i czas prowadzonych badań. Dotyczy to zarówno miast podzielonych, jak i ogólnej dostępności nauki oraz wymiany wypracowanego dorobku światowego, co także miało swoje przełożenie na ponadgraniczny transfer wiedzy. Dopiero lata dziewięćdziesiąte zapoczątkowały zainteresowanie wielokulturowością ${ }^{15}$, przynosząc m.in. szeroko aspektowe badania nad specyfika miast podzielonych $z$ jednej strony, $z$ drugiej umożliwiając prowadzenie badań i wymianę doświadczeń po obu stronach granicy (mimo ciagle jeszcze napotykanych ogromnych barier innej materii).

Wraz $z$ intensyfikacja pojawiających się analiz uwidoczniła się również różnorodność przedmiotowa prowadzonych rozważań (jednoi wielopłaszczyznowych), wśród których m.in. dominują te dotyczące ${ }^{16}$ :

12 J. Jańczak, Graniczne miasta bliźniacze jako przykład zmiany modelu polsko-niemieckiej wspótpracy granicznej po roku 2004, w: J. Jańczak, M. Musiał-Karg, Granice wewnętrzne i zewnętrzne Unii Europejskiej. Pomiędzy otwartościa a izolacja, Poznań 2011, s. 86.

${ }_{13}$ Zob. K. Kulczyńska, Miasta podzielone jako przedmiot..., s. 50.

14 R. Matykowski, Zmienność i trwałość granic w Europie, „Przegląd Zachodni” 2008, nr 3, s. 95-112.

${ }_{15}$ Zob. K. Kulczyńska, Miasta podzielone jako przedmiot..., s. 54. Autorka wymienia tu także liczne prace innych autorów powstałe $\mathrm{w}$ tym okresie podejmujące interesującą nas tematykę $z$ perspektywy różnych czynników.

${ }_{16}$ Bogatego przeglądu literatury pod tym kątem dokonała K. Kulczyńska chociażby w swoim artykule. Ibidem, s. 54-59. 
- Monotematycznych kwestii:

a) potencjału demograficznego;

b) szkolnictwa wyższego;

c) rozwoju gospodarczego, w tym handlu i usług;

d) tożsamości;

e) aktywności lokalnej;

f) języka;

g) infrastruktury i planowania przestrzennego.

- Wielowątkowych dociekań nawiązujących do:

a) przenikalności i stabilności granic, w tym tych warunkowanych procesami integracyjnymi, czy redefinicja suwerenności (wynikająca $z$ alokacji kompetencji $z$ płaszczyzny narodowej na ponadnarodowa);

b) przemian społeczno-kulturowych;

c) miasta jako przedmiotu testowania nowych metod bezpieczeństwa granic ${ }^{17}$;

d) wielokulturowości, pamięci historycznej;

e) wirtualizacji współpracy;

f) public diplomacy, w tym aktywności i inicjatyw lokalnych;

g) stabilności politycznej i historycznej odwołujacych się do korzeni historycznych, pojawiajacych się konfliktów i zwiazanych $z$ tym zmian w długości trwania granicy, czy jej międzynarodowego uznania jako efektu przemian politycznych i systemowych;

h) konsekwencji funkcjonowania granicy w poprzek miast.

- Innych pojawiajacych się zjawisk i analizowanych procesów badawczych, a mianowicie:

a) polityki top-down i botom-up;

b) procesów debounderyzacji i refrontieryzacji;

c) zmian systemowych i integracyjnych w kontekście polaryzacji regionu;

d) miast jako uczestników (aktorów) zachodzących procesów (koniec-okno-laboratorium ${ }^{18}$ );

e) polityki migracyjnej i bezpieczeństwa granic;

f) dynamiki w zakresie modelu współpracy miast (i czynników ja warunkujących);

g) miast bliźniaczych jako miast par (town couple) i miast podwójnych (double town).

17 Zob. A.M. Orumand, E. Prokkola, Border Cities, w: A.M. Orumand (ed.), The Wiley Blackwell Encyclopedia of Urban and Regional Studies 2019.

18 Zob. J. Jańczak, Graniczne miasta bliźniacze jako przykład..., s. 88. 
I jeszcze wielu innych kwestii. Warto nadmienić, iż poruszane zagadnienia, zwłaszcza te porządkujące i ujmujące badaną tematykę od strony teoretycznej, cieszą się również zainteresowaniem środowiska światowego $^{19}$ (nie tylko europejskiego), o czym w sposób wymierny świadczy chociażby liczba pobrań i cytowań dostępnych publikacji na ReaserchGate czy też innych podobnych platformach oraz bezpośrednio kierowane do autorów prośby o wersje anglojęzyczne tekstów (jeśli takowych nie ma).

\section{SILNE I SŁABE STRONY BADAŃ NAD MIASTAMI PODZIELONYMI GRANICA}

Niewątpliwie wielka zaletą badań w zakresie miast podzielonych granica jest ich duża szczegółowość i interdyscyplinarność. Nadto, choć grono osób podejmujących wspomniana tematykę jest niewielkie, to jednak badacze ci sa ekspertami w swoich dziedzinach, doskonale znajacymi realia badanej rzeczywistości i mającymi na jej temat ogromną wiedzę. Zdarza się, iż rozumieją ją i analizują znacznie lepiej niż pozostali również dzięki autopsji, gdyż albo tam zamieszkuja, albo często przebywają.

Nadto mimo pewnych deficytów w zakresie typologii miast podzielonych granica (o czym później), zauważyć można, iż pewne jej próby są systematycznie podejmowane przez poszczególnych badaczy w ich pracach i artykułach naukowych. Obecnie wielu też pracowników nauki ze środowiska międzynarodowego poszukuje, ale i wymienia się w sposób bezpośredni bieżąca wiedzą w tym zakresie, uzupełniając ja, weryfikując swoje wyniki badań, a nawet je korygujac. Personalizuje to relacje między naukowcami $z$ jednej strony i zacieśnia $z$ drugiej. Dzięki temu coraz częściej też (choć nadal jeszcze w sposób niewystarczający) dochodzi do tworzenia zespołów interdyscyplinarnych i międzynarodowych, co ma swoje przełożenie na jakość badań i ich zakres przedmiotowy oraz terytorialny. Niewatpliwie prowadzenie badań znacznie ułatwia również swoboda i możliwość szybkiego przemieszczania się $z$ miejsca na miejsce, co nie stanowi już takiego problemu, jak jeszcze kilkanaście lat temu.

19 Prawdopodobnie w przeciwieństwie do środowiska polskiego. Tutaj bowiem, jak zauważył i co mocno podkreślał prof. R. Żelichowski podczas konferencji 18 maja 2019 r. pt. „Podzielone miasta, podzielne wyspy”, iż coraz trudniej mu zainteresować wspomniana tematyką młode pokolenie studentów i doktorantów. 
Mimo dynamicznego rozwoju nauki w tym obszarze, badacze zajmujacy się tematyka miast podzielonych ciagle jeszcze napotykaja na wiele obiektywnych trudności. Dopracowania i pochylenia się wymagaja nieustannie bowiem takie kwestie jak:

- Łaczenie i standaryzowanie badań (budowanie międzynarodowych zespołów badawczych) lub ewentualnie prowadzenie ich w sposób równoległy po obu stronach granicy, zwłaszcza tych dotyczacych ujęć empirycznych ${ }^{20}$.

- Ujednolicenie aparatu pojęciowego $z$ zakresu miast podzielonych granica. Wymienić tu można chociażby rozbieżności dotyczące miast położonych po obu stronach granicy i stykających się ze soba przestrzennie: divided/duplicated/conected cities czy "miasta dwunarodowe”, „miasta dwupaństwowe” (bi-national cities), „miasta transgraniczne" (trans-border cities), "miasta na przejściach granicznych” (border-crossing cities), „międzynarodowe miasta graniczne” (international border cities), „miasta graniczne podzielone” (partioned border cities), „miasta rozpadłe” (split-up cities), „miasta bliźniacze”21, „miasta rozłupane" i pewnie jeszcze wiele innych. Różnorodność ta wynika m.in. $z$ faktu niezależnego prowadzenia badań (deficytu w zakresie transferu wiedzy) w Europie Środkowo-Wschodniej wobec reszty swiata jako efektu długoletniej izolacji będącej konsekwencją zimnowojennych podziałów politycznych.

- Brak ich typologii ${ }^{22}$, aczkolwiek należy zauważyć, iż trudu tego podjęli się R. Zenderowski, M.M. Brzezińska w swojej pracy Miasta podzielone granica państwowa $w$ nowych państwach członkowskich UE: od separacji do integracji. I są one częściowo uwzględniane w pojedynczych pracach niektórych badaczy, jak np. K. Kulczyńskiej, Miasta podzielone jako przedmiot zainteresowań geografii oraz innych nauk, czy innych prezentowanych podczas mającej miejsce w Warszawie 18 maja 2019 roku konferencji „Podzielone miasta, podzielne wyspy”.

20 Zob. A. Raczyk, S. Dołzbłasz, M. Leśniak, Relacje wspótpracy i konkurencji na pograniczu polsko-niemieckim, Wrocław 2012, s. 6.

${ }^{21}$ Zauważyć jednak trzeba, iż zdarza się, że pod jedna i ta samą nazwa funkcjonuja dwa odmienne typy miast. Dla przykładu warto dodać, iż jedni jako miasta bliźniacze określają wyłącznie miasta podzielone granica (zob. J. Jańczak, Graniczne miasta bliźniacze jako przykład..., s. 85-99), a drudzy miasta partnerskie, w tym również te podzielone granica (zob. M. Natanek, Działalność Rady Gmin i Regionów Europy w zakresie tworzenia i promocji Programu Miast Bliźniaczych $w$ Europie, w: J. Jańczak, M. Musiał-Karg, Granice wewnętrzne $i$ zewnętrzne Unii Europejskiej..., s. 54). Na taki chaos definicyjny zwraca uwagę również R. Szmytkie, Miasto podwójne jako forma osadnicza, „Przegląd Geograficzny” 2016, nr 4 (88), s. 513.

${ }^{22}$ Szerzej na ten temat pisali zarówno K. Kulczyńska, jak i R. Zenderowski, M.M. Brzezińska, Miasta podzielone... 
- Przemiany systemowe i ich skutki, jeśli chodzi o funkcjonowanie i rozwój miast ${ }^{23}$, choć dziś już nie tyle w kontekście ich demokratyzacji a europeizacji. Choć samo zjawisko integracji europejskiej jest obecne w badaniach dotyczacych miast podzielonych jako chociażby tzw. laboratoria integracji europejskiej ${ }^{24}$, to jednak dominuje spojrzenie lokalne (regionalne), natomiast brak jest perspektywy wyższych płaszczyzn, tzn. skutków oddziaływania systemów narodowych i europejskiego. Przykładowo rodzą się tutaj pytanie takie, jak chociażby te: na ile płynące $z$ UE dotacje finansowe, jako tzw. złote cugle, wymuszają określone zachowania i postawy, kształtując świadomość mieszkańców miast podzielonych (np. w zakresie preferowanych wartości, polityki gender, równouprawnienia itp.)? Jak system prawny (decentralizacja na poziomie ponadnarodowym) zmienia zakres kompetencji państw narodowych (a przez to i lokalnych), a tym samym i własnych wewnattrzpaństwowych regulacji, skutkujac przenikaniem się i „zespleceniem” polityk, zacieraniem granic w procesach decyzyjnych, w tym w zakresie polityki europejskiej i narodowej (oraz regionalnej), sprawiając, iż traca państwa, a zyskuja regiony, które same, nie mogac realizować polityki zagranicznej, de facto realizuja ja jako transgraniczna politykę regionalna ${ }^{25}$. W końcu, czy zachodzące zmiany sa symetryczne, czy asymetryczne po obu stronach granicy, w jakim stopniu i w jakim zakresie?

- Nie do końca jeszcze uświadomiony pozostaje również proces wirtualizacji świata współczesnego i przenoszenia relacji międzyludzkich, w tym również społecznościowych i lokalnych (ale przecież nie tylko), $z$ tzw. realu do sieci. Dzisiaj coraz częściej tam, chociaż na razie bardziej w sposób oddolny i nieformalny w ten właśnie sposób nawiązuje się relacje i spotyka młodzież ${ }^{26}$. Zauważalne jest również zjawisko umieszczania (trzeba przyznać licznych) informacji o inicjatywach transgranicznych na urzędowych stronach i forach internetowych, które będąc projektami odgórnymi, niestety jednak często wraz z za-

${ }^{23}$ K. Kulczyńska, Miasta podzielone jako przedmiot..., s. 59.

24 A. Gasparini, European Border Towns as Laboratories of Differentiated Integration, „ISIG Quarterly of International Sociology” 1999-2000, nr 4, s. 1, za: J. Jańczak, Integracja i dezintegracja..., s. 266.

25 Szerzej na ten temat zob. M. Giełda, Wspótpraca transgraniczna prowadzona $w$ Unii Europejskiej na podstawie programów operacyjnych realizowanych $w$ ramach Europejskiej Wspótpracy Terytorialnej, w: Wspótpraca transgraniczna $w$ administracji publicznej, red. R. Kusiak-Winter, Wrocław 2015, s. 121-139.

${ }_{26}$ Na razie nie ma takich badań, na ile Internet sprzyja i inicjuje spotkania mieszkańców miast podzielonych, chociaż samorządowcy coraz częściej dzielą się w Internecie informacjami o swoich inicjatywach i zapraszają ludność do włączenia się. Mimo to nadal panuje tu deficyt, o czym wspominali m.in. R. Zenderowski, M. Krycki, Public diplomacy..., s. 219. 
kończeniem kadencji polityków lub finalizacją projektu, odchodzą do lamusa i nie sa archiwizowane ${ }^{27}$, aktualizowane lub też nie prowadzi się relacji dotyczacych dalszych ich losów ${ }^{28}$. W zwiazku z powyższym brak jest też pogłębionych analiz dotyczacych średnio- i długoterminowych rezultatów wprowadzonych w życie i zrealizowanych pomysłów.

- Być może istotna (?), niezauważalna jeszcze przez badaczy (pozornie tylko odległa i niepowiazana) kwestia jest wpływ układu sił (bo o niej głównie mówimy) w Europie, a zwłaszcza rola największej potęgi, Niemiec, które zmieniaja oblicze Europy nie tylko gospodarczo, ale i społecznie (np. poprzez prowadzona przez kanclerz Angelę Merkel politykę „otwartych drzwi”). Jeśli weźmiemy pod uwagę, iż dzisiaj co czwarty mieszkaniec RFN ma korzenie migracyjne ${ }^{29}$, to może to $z$ czasem decydująco wpłynąc na ośrodek władzy w Niemczech i proces decyzyjny. Mając też na uwadze, iż to Niemcy sa obecnie dominantem w Europie i graja pierwsze skrzypce w UE, należy bacznie obserwować zachodzace tu przemiany i zjawiska, choć pewnie jest to zadanie dla następnego już pokolenia badaczy.

Inną też kwestią sa pojawiajace się próby decentralizacji władzy europejskiej (i niemieckiej) oraz dążenia niektórych państw (w tym Polski) do rewizji obecnego ładu geopolitycznego ograniczajacego wpływ zarówno samej UE, jak i RFN na decyzje państw narodowych. Może to m.in. skutkować silniejszym (aczkolwiek niekoniecznie „agresywnym") akcentowaniem różnic w obrębie szeroko rozumianej tożsamości, w tym tożsamości znajdującej swoje odzwierciedlenie w sferze miast podzielonych granica.

- Julita Makaro w jednym ze swych najnowszych artykułów zwraca uwage nie tyle na deficyty, ile na „przesycenie” prowadzonych badań $\mathrm{w}$ zakresie miast podzielonych granica ${ }^{30}$. Uważa bowiem, iż

27 Ibidem, s. 218-219.

28 Można tu wspomnieć chociażby o uwieńczonej sukcesem i zakończonej w 2018 r. inicjatywie „Park Mostów” („Brückenpark”) realizowanej w ramach Programu Współpracy INTERREG Polska - Saksonia 2014-2020. Projekt ten współfinansowała Unia Europejska ze środków Europejskiego Funduszu Rozwoju, https://zgorzelec.eu/projekty/park-mostowbruckenpark/ [dostęp: 9 kwietnia 2019] lub też liczne inne projekty opisane na stronie powiatu zgorzeleckiego, jak „Współpraca i komunikacja transgraniczna z wykorzystaniem metod alternatywnych i wspomagajacych”, „Centrum Ekonomii Społecznej”, „Polsko-niemieckie zawody w skokach przez przeszkody - eliminacje do finału EURO-CUP NEISSE-NYSA". Zob. http://www.powiatzgorzelecki.pl/index.php/2014-11-06-07-34-58/projekty-zrealizowane [dostęp: 9 kwietnia 2019].

29 Zob. Zeit Online, Fast jeder Vierte in Deutschland hat einen Migrationshintergrund, Zeit Online 01.08.2018, https://www.zeit.de/gesellschaft/2018-08/migration-deutschland-migrationshintergrund-bevoelkerungsanteil-statistisches-bundesamt [dostęp: 24 lutego 2019].

30 Zob. J. Makaro, On the Domination of the Integration Perspective in Academic Reflections on Polish-German Divided Towns-Selected Aspects, „Polish Sociological Review” 2019, nr 1 (205), s. 52 . 
w badanym obszarze dominuje głównie metoda zajmująca się procesami szeroko rozumianej i wieloaspektowej integracji ludności miast podzielnych. Wspomniana autorka zastanawia się, czy aby „wytrzymałość jednej pespektywy nie została już wyczerpana" i czy nie jest konieczne poszukiwanie nowych metod badawczych, które by uchwyciły rzeczywistość miast podzielonych i ukazały ja $z$ innej, nie eksplorowanej jeszcze strony ${ }^{31}$ ? Wydaje się, iż większość badaczy stara się podkreślać znaczenie czynnika wspólnotowości i procesów reintegracyjnych w obrębie miast podzielonych granica, jakby się chciało je na siłę zunifikować i scalić. Brakuje natomiast podejścia akcentującego właśnie różnorodność (tożsamościowa, kulturowa, społeczna, ekonomiczna, językowa itd.) jako bogactwo i jej wpływ na funkcjonowanie miast. Tendencje te ( $z$ różnych względów) wzmacniaja i utrwalaja istniejące ramy instytucjonalne, zarówno lokalne, państwowe, jak i europejskie, dążące do zacieśniania współpracy i promujące wspólne inicjatywy, projekty, zadania i eventy ${ }^{32}$. Miasta podzielone granica nie musza jednak na siłę rozwijać się symetrycznie i w jednakowym tempie (nie muszą też nadążać za sobą ani do tego zmierzać). Każde $z$ nich bowiem wnosi swoje indywidualne bogactwo i na swój możliwy sposób. Podejście to jest warte rozważenia, tym bardziej, iż jak zauważa Makaro, „samoregulacja ma na celu normalizację"33. Nie oznacza to oczywiście zaprzestania podjętego już wysiłku, ale uwzględnienie potrzeb społeczności lokalnej z jednej strony i poszanowanie granic (szeroko rozumianych: kulturowych, religijnych, językowych itd.) $z$ drugiej strony, tak by stworzyć w miastach podzielonych „cud normalności” ${ }^{4}$.

\section{MIASTA PODZIELONE GRANICA A TEORIA RÓL MIĘDZYNARODOWYCH}

Ponieważ prowadzone badania w zakresie miast podzielonych maja najczęściej charakter bardzo szczegółowy (a przez to często monotematyczny) kosztem ich wieloaspektowości, dlatego warto też poświęcić

${ }^{31}$ Ibidem.

32 O deficycie wielokulturowości w mieście podzielonym granica jako o swoistym „okaleczeniu” pisał m.in. R. Zenderowski, „Okaleczone miasto”. Środkowoeuropejski los Cieszyna, w: Pressje (15). Wschód - strategia czy obsesja? Kraków 2009, s. 83-93, natomiast J. Jańczak zwracał uwage na potrzebę indywidualnej analizy każdego przypadku. Zob. J. Jańczak, Miasta (trans)graniczne..., s. 61-62.

${ }_{33}$ Zob. J. Makaro, On the Domination..., s. 56.

${ }_{34}$ Zob. K. Dolińska, J. Makaro, N. Niedźwiecka-Iwańczak, Cud pogranicza? Zgorzelczanie, gubinianie $i$ słubiczanie o życiu w miastach podzielonych, Kraków 2018, s. 211. 
chwilę uwagi i na ten drugi wymiar. Choć jest on wyraźnie mniej eksplorowany, to jednak przecież nie pomijany. Jako alternatywę czy też pewna możliwość dociekań chciałabym zaproponować podejście odwołujące się do teorii ról międzynarodowych, które nie jest ani nowe, ani obce nauce (czy to socjologii, czy psychologii chociażby), ale też $z$ punktu widzenia stosunków międzynarodowych. Ta ostatnia przecież równie często, i to w zakresie interesujących nas kwestii, odwołuje się do badań nad terytorium, przestrzenią i tożsamością ${ }^{35}$ czy potęga (np. public dyplomacy jako elementem soft power), rywalizacja (konkurencja) i współpraca jako elementami takich procesów, jak balancing i bandwagoning. Brak jest natomiast ujęć obejmujących poruszane zagadnienia łącznie. Można oczywiście, ze względu na uwzględnienie wielowątkowości i wielopłaszczyznowości, zarzucić tak przyjętej perspektywie zbyt dużą ogólnikowość lub też trudność badawcza uwzględniająca mnogość zagadnień i podmiotów. $Z$ drugiej jednak strony właśnie taka analiza jest w stanie dać pełniejszy, nie oderwany od rzeczywistości, obraz miast podzielonych i jednocześnie scalić badania w tym zakresie, w którym wcześniej były one rozproszone.

Jeśli państwa, jako aktorzy w ramach stosunków międzynarodowych, odgrywaja swoje role, to to samo można powiedzieć o miastach podzielonych granica. Justyna Zając zauważa, iż „role mogą odgrywać wszyscy aktorzy stosunków międzynarodowych, zarówno państwa, jak i podmioty niepaństwowe" ${ }^{36}$. Zatem stwierdzić możemy, iż również miasta odgrywaja swoje (najczęściej regionalne, choć nie tylko) role, które niejednokrotnie właśnie, ze względu na specyfikę położenia, maja wpływ zarówno na politykę wewnętrzna państwa, w którym sa usytuowane, jak i politykę zagraniczna czy też przygraniczna drugiego kraju (choć oczywiście w sposób pośredni i w decydująco mniejszym stopniu).

Nie do końca $z$ poglądem tym zgadza się Piotr Bartosiewicz, który $z$ kolei uważa, iż teoria ról odnosi się głównie do państw, ale przyznaje, iż w obszar ten zaczynaja pomału wkraczać organizacje międzynarodowe, choć te traktowane sa (przynajmniej na razie) drugoplanowo ${ }^{37}$. Podkreśla jednak, iż od strony metodologicznej teoria ról międzynarodowych może pełnić rolę „łącznika” czy „pomostu” między różnymi

${ }^{35}$ Zob. np. T. Burdzik, Przestrzeń jako składnik tożsamości $w$ świecie globalizacji, „Kultura - Historia - Globalizacja” 2012, nr 11.

${ }^{36}$ J. Zając, Teoria ról międzynarodowych, w: R. Zięba, S. Bieleń, J. Zając, Teorie i podejścia badawcze $w$ nauce o stosunkach międzynarodowych, Warszawa 2015, s. 127.

37 Zob. P. Bartosiewicz, Zagadnienie ról międzynarodowych państw $w$ internacjologii, „Polityka i Społeczeństwo” 2007, nr 4, s. 7. 
podejściami badawczymi. Przy analizie istoty miast podzielonych granica jest to o tyle ważne, iż prowadzone tutaj badania coraz częściej maja charakter interdyscyplinarny. Zwracaja na to uwage m.in. Kulczyńska czy Zenderowski i Brzezińska.

Definicji ról jest bardzo wiele i choć samo pojęcie zostało przejęte $z$ obszaru sztuki teatralnej, to na stałe już zakorzeniło się w politologii, socjologii, psychologii i nauce o stosunkach międzynarodowych ${ }^{38}$. Rola jest funkcja nakładających się czynników, takich jak: polityka wewnętrzna i zewnętrzna, systemy międzynarodowe, w których dany podmiot funkcjonuje, oraz przyjęta (i akceptowana lub nie przez środowisko międzynarodowe) koncepcja roli ${ }^{39}$.

Ogromne znaczenie maja także uwarunkowania wewnętrzne i zewnętrze, które choć odnoszą się wprawdzie do państw, to jednak $z$ łatwościa można je również przypisać podzielonym granica miastom. Sa to: położenie geograficzne, potencjał demograficzny i ekonomiczny, system społeczno-polityczny oraz charakter otoczenia międzynarodowego, wymagania i oczekiwania narzucone przez środowisko zewnętrzne (międzynarodowe), pozycja w systemie międzynarodowym oraz liczba i jakość sojuszy ${ }^{40}$. Oczywiście nie wszystkie wspomniane kategorie pasują do sytuacji miast podzielonych granica. Niektóre bowiem, jak dwa ostatnie, są wprawdzie domena typowo państwowa, ale biorąc pod uwagę, iż także interesujący nas podmiot badań posiada swoją własna pozycję w kraju (zazwyczaj jednak marginalną i niewykorzystywana) oraz ze względu na swe położenie zawiera szereg umów partnerskich na realizację wspólnych zadań, również i ta kategoria, oczywiście w wersji odpowiednio przystosowanej, znajduje swoje uzasadnienie.

Jeśli spróbujemy przyjrzeć się miastom pod względem ich wzajemnej pozycji, to istotne znaczenie odgrywa tutaj zjawisko symetryczności (asymetryczności) zachodzacych procesów. Widoczne jest ono zarówno w aspekcie przestrzeni (terytorium) jak i ludności ${ }^{41}$. Katarzyna Kulczyńska zauważa, iż największe dysproporcje pod względem liczby ludności i terytorium zachodzą w miastach Słubice i Frankfurt (n. Odra), Gorizia i Nova Gorica, Rheinfelden i Rheinfelden (Baden), Tornio i Haparanda, Narva i Ivangorod, Watykan i Rzym. Najmniej-

\footnotetext{
${ }^{38}$ J. Zając, Teoria ról międzynarodowych..., s. 128.

39 Zob. P. Bartosiewicz, Zagadnienie ról..., s. 8-9.

40 Ibidem, s. 9.

${ }^{41}$ Więcej na ten temat pisze K. Kulczyńska, Miasta podzielone w Europie, „Studia Miejskie" 2014 , t. 15 , s. 105-113.
} 
sza asymetria zaś widoczna jest na granicy polsko-niemieckiej w miastach Łęknica i Bad Muskau ${ }^{42}$.

Prowadzac rozważania nad znaczeniem i rola miast podzielonych granica, nie sposób pominąć kwestii stopnia i charakteru ich kooperacji. Kluczowe pytania oraz ciekawe refleksje $\mathrm{w}$ tej materii, przedstawił Jarosław Jańczak w swoim artykule Graniczne miasta bliźniacze jako przykład zmiany modelu polsko-niemieckiej wspótpracy granicznej po roku $2004^{43}$. Zwrócił on mianowicie uwagę, iż po 1989 roku (Jesień Ludów) nastapiła zmiana autopercepcji miast podzielonych, które z roli „końca terytorium” zaczęły dążyć do bycia „mostem” i „oknem na świat”, stając się „laboratoriami integracji europejskiej”. Poszukiwały one bowiem „nowej formuły przełamujacej peryferyjne położenie i niedogodności rozwojowe $z$ nim zwiazane"44. Proces ten dodatkowo wzmocniło członkostwo Polski w UE i przystapienie do strefy Schengen. Poczatkowo jednak, $z$ powodu znacznych różnic $w$ zakresie infrastruktury i funkcjonowania instytucji po stronie polskiej i niemieckiej, pierwsze inicjatywy integracyjne na terenie analizowanych miast wzorowały się na modelu top-down i charakteryzowały się przede wszystkim centralizacją, odgórna akceptacja polityczną i wsparciem finansowym wyższych płaszczyzn decyzyjnych. To głównie szczebel administracyjny, jak zauważa Jańczak, był inspiratorem, pomysłodawca i realizatorem inicjatyw transgranicznych, stając się niejako „motorem integracji” miast bliźniaczych. $Z$ czasem jednak to „planistyczne” i „zinstytucjonalizowane” zaangażowanie na tyle skutecznie się zakorzeniło i przyjęło $\mathrm{w}$ świadomości mieszkańców podzielonych miast, iż stopniowo model działania zaczą przybierać formę oddolna bottom-up. W efekcie zmianie uległ nie tylko podmiot działajacy, ale i zakres podejmowanych inicjatyw. Przeszedł on bowiem ze sfery symboliki i pojedynczych projektów na obszar rzeczywistych zmian systemowych. Wraz ze spadkiem aktywności władz centralnych, inicjatywę współpracy transgranicznej i pogłębiania integracji przejęły władze lokalne i tamtejsza społeczność, biorąc sprawy w swoje ręce. Przejawiało się to m.in. inicjatywami oddolnymi, w większym stopniu uwzględniającymi potrzeby społeczeństw mieszkających po obu stronach granicy. Miasta podzielone granica zaczęły stawać się „dwumiastami", a nie dwoma miastami ${ }^{45}$, nasilajac proces deboundaryzacji ${ }^{46}$.

\footnotetext{
42 Zob. K. Kulczyńska, Miasta podzielone w Europie..., s. 108.

43 Zob. J. Jańczak, Graniczne miasta bliźniacze jako przykład..., s. 85-99.

44 Ibidem, s. 88.

45 Ibidem, s. 89-92.

46 J. Jańczak, Integracja i dezintegracja..., s. 272.
} 
Wraz ze wzrostem nastrojów proeuropejskich i zwiększaniem przepuszczalności granicy państwowej (w obrębie dzisiejszych granic wewnętrznych UE) zainteresowanie władz centralnych miastami podzielonymi granica znaczaco spadło, a nawet bywało „blokowane”. Ponownie zaczałł następować proces „odsuwania” miast bliźniaczych na peryferie prowadzonej przez państwa polityki, co wynikało głównie z obaw o erozję tożsamości narodowej. Nasilił się więc odwrotny do przedakcesyjnego proces defrontieryzacji, szczególnie widoczny w obrębie tych miast, które wcześniej charakteryzowały się konfliktogenna historia i trudnymi relacjami ${ }^{47}$.

Istotnymi czynnikami wpływającymi na pozycję miast podzielonych granica sa także aspekty gospodarcze, gdzie przestrzeń, lokalizacja i miejscowe uwarunkowania, staja się kluczowe dla budowania atrakcyjności i konkurencyjności regionu ${ }^{48}$. I choć, jak stwierdza Andrzej Raczyk, pogranicze może sprzyjać zarówno konkurencji, jak i z powodu braku sieci powiazań, nasilać niezależność obszarów znajdujacych się po obu stronach granicy ${ }^{49}$, to jednak każdy przypadek jest indywidualny i ma swoje własne uwarunkowania.

Dla przykładu warto zatrzymać się tutaj nad dwoma skrajnymi kazusami: pierwszym dotyczacym relacji polsko-niemieckiego pogranicza i polsko-niemieckich miast oraz drugim nawiąującym do sytuacji w Cieszynie i Czeskim Cieszynie. Jak podaje Małgorzata Leśniak-Johann, rozwój pogranicza polsko-niemieckiego od początku lat dziewięćdziesiątych cechował się aktywnością strony niemieckiej i pasywnościa strony polskiej (m.in. ze względu na brak ramowych wytycznych dotyczacych prowadzenia polityki zagranicznej). W efekcie, współpraca przybierała tam formę „monolog[u] strony niemieckiej"50. Poszczególne koncepcje wysuwane przez Niemców spotykały się bowiem $z$ niechęcią Polaków obawiających się „podporządkowania ziem zachodnich interesom niemieckim oraz stworzenia zaplecza turystycznego dla Berlina" czy dominacji gospodarki niemieckiej ${ }^{51}$.

Inne natomiast badania, przeprowadzone przez Kamillę Dolińska, Julitę Makaro oraz Natalię Niedźwiecką-Iwańczak ${ }^{52}$, wskazuja,

47 Ibidem, s. 271-274.

48 Zob. A. Raczyk, Relacje wspótpracy i konkurencji - ujęcie teoretyczne, w: E. Marks, Relacje wspótpracy i konkurencji na pograniczu polsko-niemieckim, Wrocław 2012, s. 78.

49 Ibidem, s. 61.

50 M. Leśniak-Johann, Uwarunkowania rozwoju relacji polsko-niemieckich obszarów pogranicza, w: E. Marks, Relacje wspótpracy i konkurencji..., s. 150.

${ }_{51}$ M. Leśniak-Johann, Uwarunkowania rozwoju..., s. 151-152.

52 Zob. K. Dolińska, J. Makaro, N. Niedźwiecka-Iwańczak, Cud pogranicza?..., Kraków 2018. 
iż mieszkańcy Słubic, Gubina i Zgorzelca ${ }^{53}$ dzisiejsza perspektywę rozwoju miast przygranicznych postrzegaja raczej jako współpracę i zbliżanie się do siebie (poprzez zacieranie różnic), a nie dominacje jednego nad drugim, choć takich obaw nie wykluczaja ${ }^{54}$. Tutaj jednak, podobnie jak na obszarze przygranicznym, daje się słyszeć głosy, iż: „robimy wszystko pod Niemców i wszyscy próbuja dostosować ofertę do niemieckich potrzeb, np. zakłady fryzjerskie, sklepy z papierosami i alkoholem”, czy też „pełno, za dużo Niemców, jesteśmy rozjeżdżani przez Niemców"55. Należy jednak zauważyć, iż opinie te opierają się na subiektywnych odczuciach (narracji mieszkańców), a nie na obiektywnych danych.

Odwrotnie sytuacja wygląda na granicy polsko-czeskiej. Zenderowski i Brzezińska dla przykładu podaja, iż kooperacja w miastach Cieszyn-Czeski Cieszyn ma charakter polsko-polski, a nie polsko-czeski, ze względu na dominację polskiego Cieszyna i znaczną liczbę Polaków mieszkających po czeskiej stronie. Można więc powiedzieć, iż akurat w tym przypadku Cieszyn odgrywa rolę dominanty względem Czeskiego Cieszyna, przejmując jego zadania w zakresie współpracy transgranicznej i monopolizując je ${ }^{56}$.

Wśród miast podzielonych granicą są też oczywiście takie, jak np. Gorizia-Nowa Gorica, Bad Radkersburg-Gornja Radgona, których potencjał ekonomiczny i rozwój gospodarczy są do siebie bardzo zbliżone. Ułatwia im to współpracę i integrację, a badaczom prowadzenie badań.

W kontekście studiów odnoszacych się do soft power miast podzielonych granica to i tutaj również prowadzone były częściowe badania. Wystarczy odwołać się do analizy dotyczącej public dyplomacy w Cieszynie i Czeskim Cieszynie ${ }^{57}$, która obrazuje przegląd siły oddziaływania jednej części miasta na druga w zakresie kultury, nauki i informacji.

W zakresie możliwości społeczno-kulturowych miast podzielonych granica, tutaj również zauważalne sa dysproporcje. Wymienić chociażby można Slovenské Nové Mesto-Sátoraljújhely, bez bazy instytucjonalnej, odgrywające rolę „sypialni”, Cieszyn i Czeski Cieszyn, gdzie kulturalnie dominuje strona polska, czy w końcu Bad Radkersburg-Gornja Radgona o zbliżonych potencjałach ${ }^{58}$.

53 Niestety, tutaj znowu zauważyć można deficyt w zakresie łączenia i standaryzacji badań po obu stronach granicy. Analiza dotyczy bowiem tylko miast po polskiej stronie.

${ }_{54}$ Zob. K. Dolińska, J. Makaro, N. Niedźwiecka-Iwańczak, Cud pogranicza?..., s. 136.

55 Ibidem, s. 116.

56 Zob. R. Zenderowski, M.M. Brzezińska, Miasta podzielone..., s. 180.

57 R. Zenderowski, M. Krycki, Public diplomacy..., 2014.

58 Zob. R. Zenderowski, M.M. Brzezińska, Miasta podzielone..., s. 172. 
Wprawdzie analizowane podmioty, ze względu na brak paralelnych badań w tej materii, różnią się między soba (zarówno terytorialnie, jak i zastosowana metoda badawcza), to jednak moga (choć nie musza) dawać pewne wyobrażenie o panującej w regionie i w samych miastach bliźniaczych sytuacji oraz zachodzacych tam relacjach. Moga też stać się interesującym przyczynkiem do dalszych rozważań nad podobieństwem procesów zachodzących między miastami bliźniaczy$\mathrm{mi}$ a regionami, w których sa umiejscowione. Jest to tym ciekawsze, że coraz częściej miasta podzielone granica poszukują partnerów do współpracy nie u swojego asymetrycznego „bliźniaka”, ale w miastach o podobnym potencjale, ulokowanych $\mathrm{w}$ regionie lub nawet po drugiej stronie granicy. Wynika to $z$ faktu, iż we wzajemnych relacjach raczej nastawiają się one na współpracę i uzupełnianie swoich potencjałów, podczas gdy jako część regionu wolą konkurować ${ }^{59}$. Wspomniane przykłady wyraźnie też wskazują na pojawianie się (w zależności od wielu różnych uwarunkowań), mimo deklarowanej współpracy, tendencji do dominacji jednej części miasta nad druga, co bierze swój poczatek $z$ asymetrii ich potęg.

Zakładając, iż odgrywanie roli nierozerwalnie związane jest $z$ tożsamością, należy zwrócić uwagę, iż oba wspomniane elementy analizy są dynamiczne i zmienne w czasie. Kształtowanie się bowiem tożsamości rodzi się nie tylko poprzez autoidentyfikację, ale także poprzez konfrontację $z$ innymi (me vis-à-vis others) oraz uwzględnianie oczekiwań i zachowań innych (expectation and behawior of others) ${ }^{60}$.

$Z$ perspektywy miast bliźniaczych brak jest niestety rozważań łączących wymienione wyżej aspekty w jednym ujęciu. Przyznać jednak trzeba, że niektórzy badacze starają się uwzględniać ich jak największa liczbę, co daje podstawę do zastosowania w przypadku miast podzielonych granica właśnie założeń teorii ról międzynarodowych. Pozwoliłoby to $z$ jednej strony na poszerzenie obecnych badań, połączenie ich $\mathrm{w}$ jeden projekt badawczy, a także, co istotne, stworzyłoby możliwość nieco innego spojrzenia na problematykę miast podzielonych granica.

\section{WNIOSKI KOŃCOWE}

Odpowiadając na postawione we wstępie pytania, należałoby stwierdzić, iż miasta podzielone granica nie tylko moga, ale i de facto też ods. 93.

59 Zob. więcej na ten temat: J. Jańczak, Graniczne miasta bliźniacze jako przykład...,

60 Zob. S. Harnisch, Role theory. Operationalization of key concept, w: S. Harnisch, C. Frank, H.W. Maull, Role Theory in International Relations, New York 2011, s. 11. 
grywają różne międzynarodowe role. Czynią to na wielu płaszczyznach: lokalnej i regionalnej, oraz ze względu na swój charakter i specyfikę, również na płaszczyźnie narodowej i międzynarodowej ${ }^{61}$. Niemniej, w miarę poszerzania się (lub redukowania) obszaru ich oddziaływania (przestrzennego, kulturowego, językowego, religijnego itd.), natura ich wpływów się zmienia. Zmienna jest zatem również i ich rola.

Jeśli chodzi o percepcję i akceptację ról odgrywanych przez analizowane miasta, odpowiedź nie jest szablonowa. Na przykład na polsko-niemieckim pograniczu rola dominacji jednej części miasta (tu: niemieckiej) jest połowicznie akceptowana przez mieszkańców strony polskiej, a częściowo zaś budzi jej sprzeciw. Zatem rola rzeczywista przejawiająca się jako dominacja, odbiega od roli wyobrażonej (opartej na współpracy) po stronie polskiej, po stronie niemieckiej jest spójna (zgoda co do dominacji jak i dominowania). Podobnie dzieje się w Cieszynie i Czeskim Cieszynie, gdzie rolę dominanta odgrywa strona polska. Może się jednak też zdarzyć, iż rola wyobrażona jest spójna $z$ rzeczywista. Każdy jednak przypadek miasta podzielonego granica jest inny i wymaga oddzielnych analiz.

O tym, jak zachowaja się miasta podzielone granica, a zatem, czy będą ze sobą konkurować na płaszczyźnie lokalnej, czy współpracować w regionie (lub odwrotnie), czy też przyjma jeszcze inny kierunek działań zależy od ich strategii. Czynnikiem zaś decydujacym jest tu przede wszystkim ich potęga, która po pierwsze warunkowana jest kwestiami finansowymi (tzw. hard power „twarda siła”) i po wtóre zależy od stażu integracyjnego, dziedzictwa konfliktu bądź współpracy, podobieństwa kulturowego, językowego, religijnego, czynnika demograficznego, położenia itd. (tzw. soft power „miękka siła”) ${ }^{62}$. Oba czynniki w istotny sposób wpływaja na kształtowanie się modelu współpracy ${ }^{63}$, choć należy zauważyć, iż ich nasilenie (lub osłabienie) też może być różne w każdym przypadku. Warto zbadać kwestię, czy miasta wykorzystuja w swej aktywności na poszczególnych poziomach miękką i twardą siłę w jednakowym stopniu, a jak nie, to która bardziej i dlaczego?

Konsekwencje przyjętych przez miasta podzielone granica działań i strategii, na każdej z płaszczyzn, również są odmienne. Od wspomnianej dominacji lub zjawiska bycia zdominowanym na płaszczyźnie

\footnotetext{
${ }^{61}$ Więcej na ten temat np. R. Kusiak-Winter, Wspótpraca transgraniczna gmin Polski i Niemiec, Wrocław 2011.

${ }^{62} \mathrm{O}$ hard power i soft power zob. J.S. Nye, The Powers to Lead, Oxford 2008, s. 27-52, ale też i inne dzieła tegoż autora.

63 Zob. J. Jańczak, Miasta (trans)graniczne..., s. 57-58.
} 
lokalnej do współpracy i konkurencji z pozostałymi ośrodkami w regionie, niezależnie od tego, czy znajduja się one na pograniczu, czy też nie. Część miast podzielonych granica wychodzi bowiem $z$ założenia, iż bardziej opłacalna jest dla nich multiplikacja ich potencjału niż wzajemna konkurencja. Łączą się zatem w działaniu i wykorzystuja swoja „zjednoczona” siłę do rywalizacji z innymi ośrodkami. Zwracał na to uwage $w$ swoich badaniach już Jarosław Jańczak ${ }^{64}$, a empirycznie sytuacja ta jest szczególnie zauważalna na polsko-niemieckim pograniczu. Jak pokazuje doświadczenie, niemieckie części miast podzielonych maja bowiem bardzo mała siłę oddziaływania na swój region. Władze federalne borykaja się tam nieustannie $z$ dużym, $\mathrm{w}$ stosunku do reszty regionu i kraju, deficytem demograficznym ${ }^{65}$ i brakiem rak do pracy ${ }^{66}$, zachęcając Polaków do zamieszkania po niemieckiej stronie ${ }^{67}$. Spotyka się to też $z$ częściowym zainteresowaniem strony polskiej. Również i o tym pisał Jańczak: „w konkurencji z innymi ośrodkami miejskimi, sięgając po zasoby partnera, miasto poprawia własna pozycję" ${ }^{68}$. Zdaje się, że opinię tę rozumieją i popieraja sami mieszkańcy Zgorzelca i Görlitz: „para razem [to] miasto średniej wielkości” (Zgorzelec), to „nowe centrum” (Zgorzelec), które jest „położone na obrzeżach, ale $z$ rosnącymi funkcjami centralnymi” (Görlitz) ${ }^{69}$.

Zatem teoria ról międzynarodowych może stać się interesującym narzędziem do badania zachowań miast podzielonych granica chociażby ze względu na dwa fakty: po pierwsze, na zachodzące wewnątrz nich procesy, a po drugie, na ich relacje w kontekście $z$ innymi. Pozwala też ocenić, na której z płaszczyzn zachowuja się one bardziej aktywnie i czy ich potęga, w perspektywie czasu i przestrzeni zmienia się, a jeśli tak, to w jakim zakresie i co na to wpływa?

Nadto ciekawe, wymagajace dalszych, pogłębionych i indywidualnych już badań, byłyby kwestie dotyczace tego, jak miasta podzielone buduja swoja potęge i $z$ czego ja czerpia oraz czy potrafia świadomie, na różnych płaszczyznach oddziaływania z niej korzystać i ja „pomna-

64 Ibidem, s. 61.

65 Wiele na ten temat chociażby w prasie lokalnej, m.in. np. zob. „Wiadomości Zgorzelec. Nasze Miasto", Pogranicze: Piękne ale puste miasto..., https:/ /zgorzelec.naszemiasto.pl/ pogranicze-piekne-ale-puste-miasto/ar/c1-3963088 [dostęp: 13 września 2019].

66 Zob. P. Słowiński, Tysiace Polaków pracuje w Görlitz, Radio Wrocław, 6 sierpnia 2015, https://www.radiowroclaw.pl/articles/view/44377/Tysiace-Polakow-pracuje-w-Gorlitz [dostęp: 13 września 2019].

67 Zob. Red., Pieniądze to nie wszystko? Mieszkanie w Goerlitz kluczem do szczęścia? 11 lipca 2017, https://www.zinfo.pl/artykuly/24115 [dostęp: 13 września 2019].

68 J. Jańczak, Miasta (trans)graniczne..., s. 61.

69 Ibidem, s. 61. 
żać”? Jak zachowuja się na płaszczyźnie narodowej i międzynarodowej; jak kształtuje się siła ich oddziaływania, czy maja jej świadomość i czy wykorzystuja swoje możliwości również w szerszej (przestrzennie) perspektywie?

Przy tym wszystkim należy jednak pamiętać, iż nie wszystkie miasta podzielone granica sa asymetryczne. Znane sa również przypadki, gdzie zachowana jest równowaga potęg, a zatem i odgrywane przez takie miasta role sa $z$ pewnościa inne. Wszystko to jednak wymaga dalszych analiz i szczegółowych badań, a teoria ról może okazać się tutaj pomocnym i ciekawym, choć nie pozbawionym mankamentów, narzędziem. 